\title{
Twenty Years of Water-Quality Studies in the Cheney Reservoir Watershed, Kansas, 1996-2016
}

\section{By Jennifer L. Graham, Guy M. Foster, and Ariele R. Kramer}

\section{Introduction}

Cheney Reservoir, located in south-central Kansas (fig. 1), is one of the primary drinking-water supplies for the City of Wichita and an important recreational resource for the region. Because of population growth, urban development, and watersupply needs, the City of Wichita will continue to rely on Cheney Reservoir as a drinking-water source for the foreseeable future. Cyanobacterial blooms in Cheney Reservoir during 1990 and 1991 caused severe taste-and-odor events and prompted the formation of the Cheney Reservoir Task Force in 1992. The task force identified nutrients and sediment as primary pollutants of concern in the Cheney Reservoir watershed because of their effects on water quality and quantity and their relation to cyanobacterial blooms. Consequently, stream-water-quality goals for nutrients and sediment were established in an effort to improve water-quality conditions in Cheney Reservoir (Cheney Reservoir Task Force, 1994).

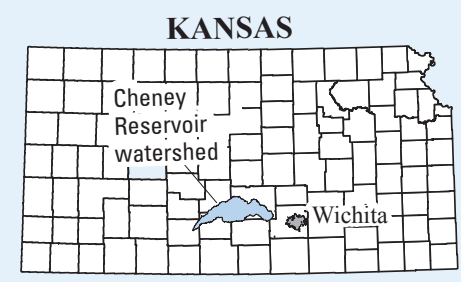

\section{EXPLANATION}

○ 1996 to 2001 study site

$\triangle$ Long-term (1996 to present) continuous water-quality monitoring study site

Figure 1. Location of U.S. Geological Survey study sites in the Cheney Reservoir watershed during 1996-2016.

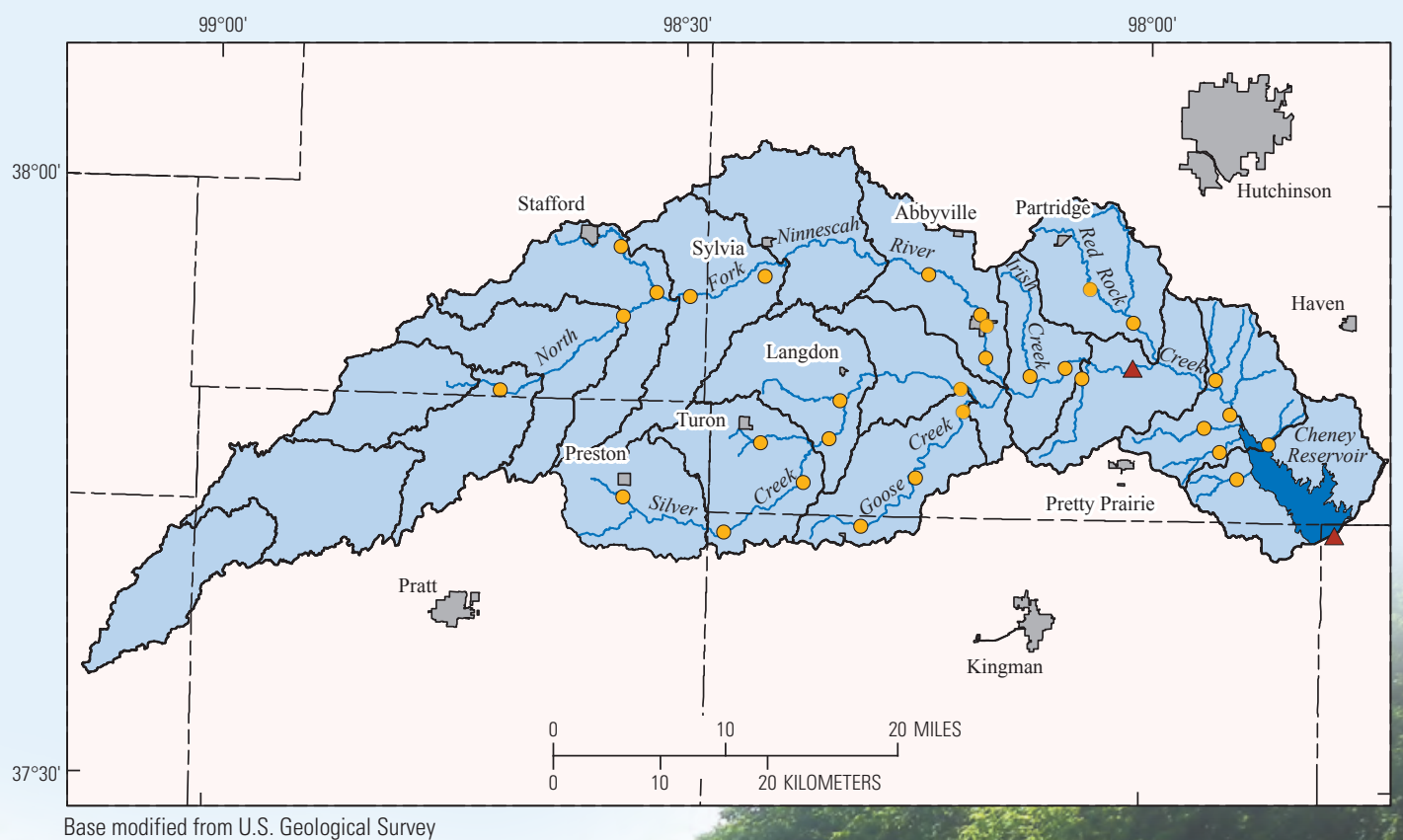

Since 1996, the U.S. Geological Survey (USGS), in cooperation with the City of Wichita, has done studies in the Cheney Reservoir watershed to understand environmental effects on water-quality conditions (fig. 1). Early studies (1996-2001) determined subwatershed sources of contaminants, nutrient and sediment loading to Cheney Reservoir, changes in reservoir sediment quality over time, and watershed sources of phosphorus. Later studies (2001-present) focused on nutrient and sediment concentrations and mass transport from the watershed; the presence of cyanobacteria, cyanotoxins, and taste-and-odor compounds in the reservoir; and development of regression models for real-time computations of water-quality constituents of interest that may affect drinking-water treatment. This fact sheet summarizes key results from studies done by the USGS during 1996-2016 in the Cheney Reservoir watershed and Cheney Reservoir. 


\section{Watershed Studies}

Water-quality conditions in the watershed can be compared to the goals established by the Cheney Reservoir Task Force (1994). No discernible patterns were evident in nutrient or suspended-sediment concentrations or loads during 1996 through 2013, largely because of hydrologic variability (Stone and others, 2013; Stone and others, 2015). To determine the long-term effects of watershed investments in best management practices (BMPs), more rigorous analyses are needed.

\section{Total Phosphorus}

Agricultural activities have increased the total phosphorus concentrations in soil to about three times natural conditions (unaffected by human activity). As a result, an estimated 65 percent of the phosphorus transported to Cheney Reservoir is from agricultural sources (Pope and others, 2002). Reservoir sediment cores were used to construct a historical water-quality record and indicate increasing trends in phosphorus concentrations during the life of the reservoir (1965-98), likely the result of nonpoint-source activities in the watershed, such as increased fertilizer use and livestock production (Mau, 2001). Phosphorus concentrations were generally larger in the eastern part of the watershed and smaller in the western part (Pope and others, 2002). During 1997-2000, total phosphorus concentrations in five subwatersheds exceeded the Cheney Reservoir Task Force longterm goal ( 0.1 milligrams per liter) by two to five times (fig. 2 ). Natural phosphorus conditions in three of the five subwatersheds also equaled or exceeded the long-term goal (Pope and others, 2002). During 1997-2012, the long-term total phosphorus goal was exceeded about 60 percent of the time (Stone and others, 2013). Combined, these findings indicate that established goals may not be attainable without a substantial amount of BMPs implemented in the eastern part of the watershed.

\section{Suspended Sediment}

Sediment accumulation in Cheney Reservoir was less than expected as of 2001; only 4 percent of the reservoir's original storage capacity was lost to sedimentation (Mau, 2001). During 1965 through 1998, only 27 percent of the inactive conservation storage pool had been filled (less than the estimated 34 percent by design). Substantial suspended-sediment loads have been delivered to Cheney Reservoir during very short time periods with extreme hydrological conditions (fig. 3). Forty-one percent of the sediment load transported to Cheney Reservoir during 1966 through 2013 was delivered during 8 days (Stone and others, 2015). The estimated sediment load in 1979 alone accounted for 20 percent of the total load to the reservoir during a 48 -year period. Ninety-two percent of the sediment delivered to the reservoir in 1979 was delivered in 1 day during an approximately 100-year flood event ( 1 in 100 chance of being equaled or exceeded in any 1 year). Because of the episodic nature of sediment loading to the reservoir, sediment management plans will need to address large and infrequent inflow events.

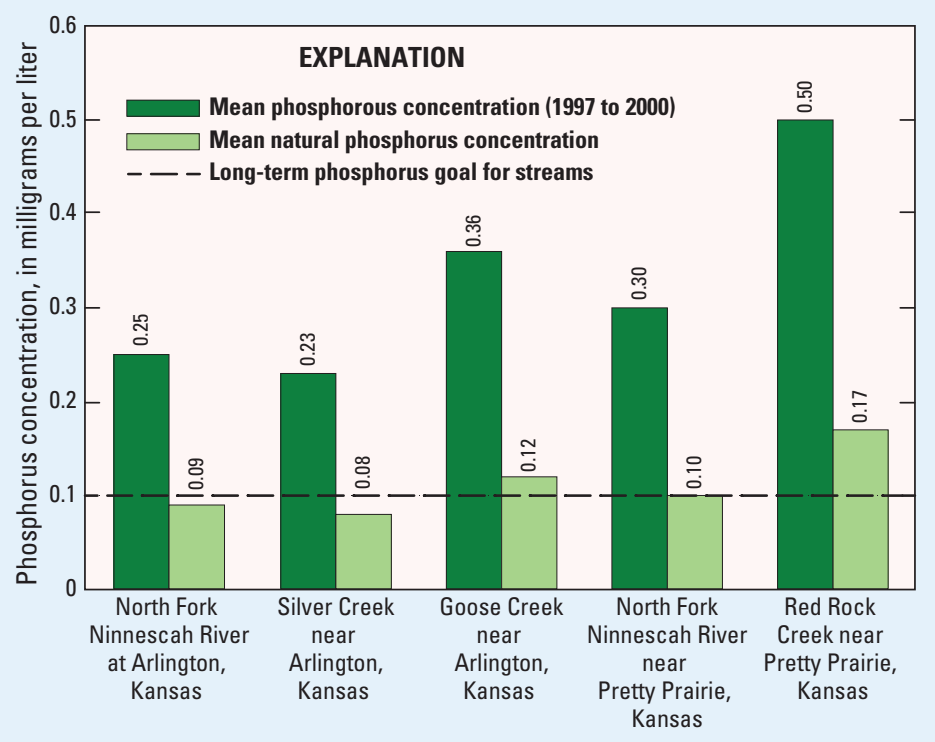

Figure 2. Comparison of measured and estimated natural phosphorus concentrations in water samples from five surfacewater-quality sampling sites in the Cheney Reservoir watershed. Figure after Pope and others, 2002.

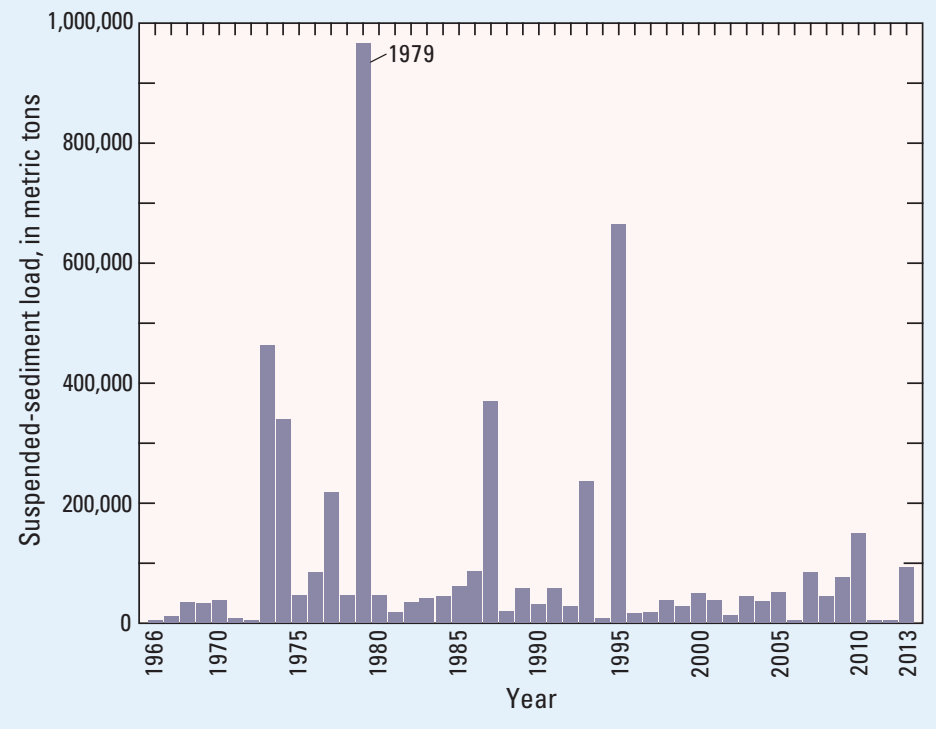

Figure 3. Computed annual suspended-sediment loading to Cheney Reservoir, 1966-2013. Figure after Stone and others, 2015.
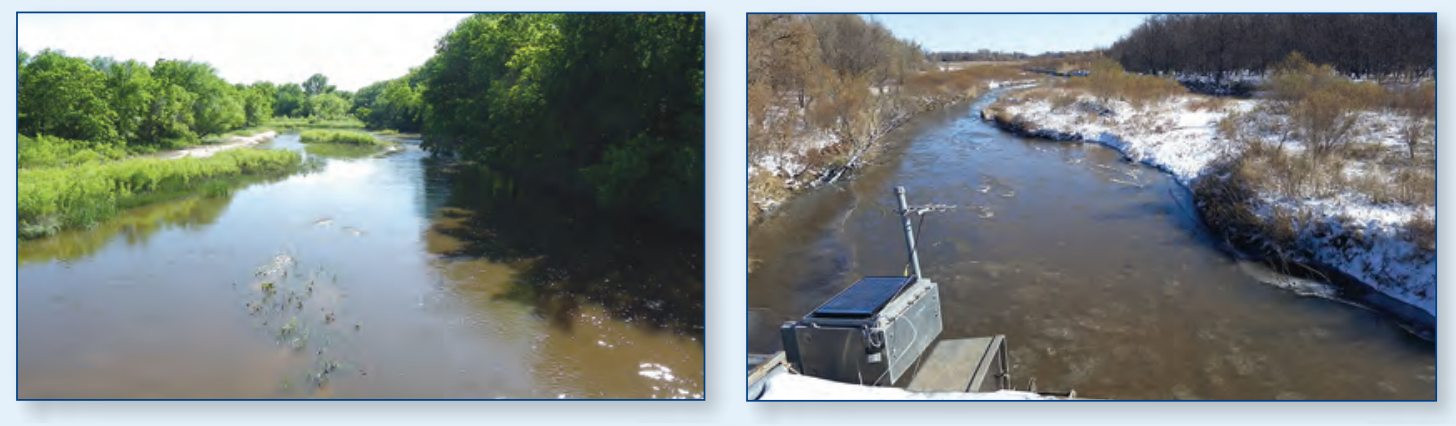

North Fork Ninnescah River, south-central Kansas in June (left) and November (right). Photographs by U.S. Geological Survey. 


\section{Reservoir Studies}

Cyanobacteria, microcystin (a cyanotoxin), and geosmin (a taste-and-odor compound) were detected in about 84, 52, and 31 percent, respectively, of samples collected from Cheney Reservoir during 2001 through 2016. 2-methylisoborneal (MIB, a taste-and-odor compound) was less common and was detected in only 4 percent of samples. Microcystin and geosmin concentrations exceeded advisory values of concern more frequently than cyanobacterial abundance; therefore, cyanobacteria are not a good indicator of the presence of these compounds in Cheney Reservoir (Graham and others, 2017). Cyanobacteria-related events are therefore an episodic, rather than a chronic, waterquality concern in Cheney Reservoir.

Seasonal patterns in cyanobacteria and microcystin were evident, though abundance and concentration varied by orders of magnitude across years (fig. 4). Cyanobacterial abundances generally peaked in late summer or early fall, with smaller peaks observed in winter. Microcystin was first detected in June or July, increased to maximum concentrations in summer, and then decreased. Seasonal patterns in geosmin were less consistent than cyanobacteria and microcystin; there was generally a small geosmin peak during winter in most years and a larger peak during summer in some years (Graham and others, 2017). Geosmin peaks during summer were relatively uncommon until summer 2013. An August 2013 inflow stimulated a geosmin event in the reservoir that had the highest late summer and fall concentrations observed during 2001 through 2016 (Graham and others, 2017; Otten and others, 2016). High geosmin concentrations have been observed in late summer and fall since the 2013 inflow event, which demonstrates that changing environmental conditions affect seasonal patterns in cyanobacteria, microcystin, and taste-and-odor compounds in Cheney Reservoir.

Genetic analyses have identified the cyanobacterial genera Microcystis and Anabaena as the most likely microcystin and geosmin producers, respectively, in Cheney Reservoir (Otten and others, 2016). The likely producer of MIB has not been identified in Cheney Reservoir, though benthic, rather than planktonic, cyanobacteria have been hypothesized as a potential source; benthic algal communities in Cheney Reservoir have not been studied. Identification of the likely producers of microcystin and geosmin allows future analyses of environmental influences to be more specific, rather than focusing on the entire cyanobacterial community. Presence of these organisms may additionally serve as an indicator of potential microcystin or geosmin events.

The presence of cyanobacteria, microcystin, and geosmin in Cheney Reservoir has been linked to nutrient and sediment concentrations (Christensen and others, 2006; Harris and others, 2016). There is generally a positive association with nutrient
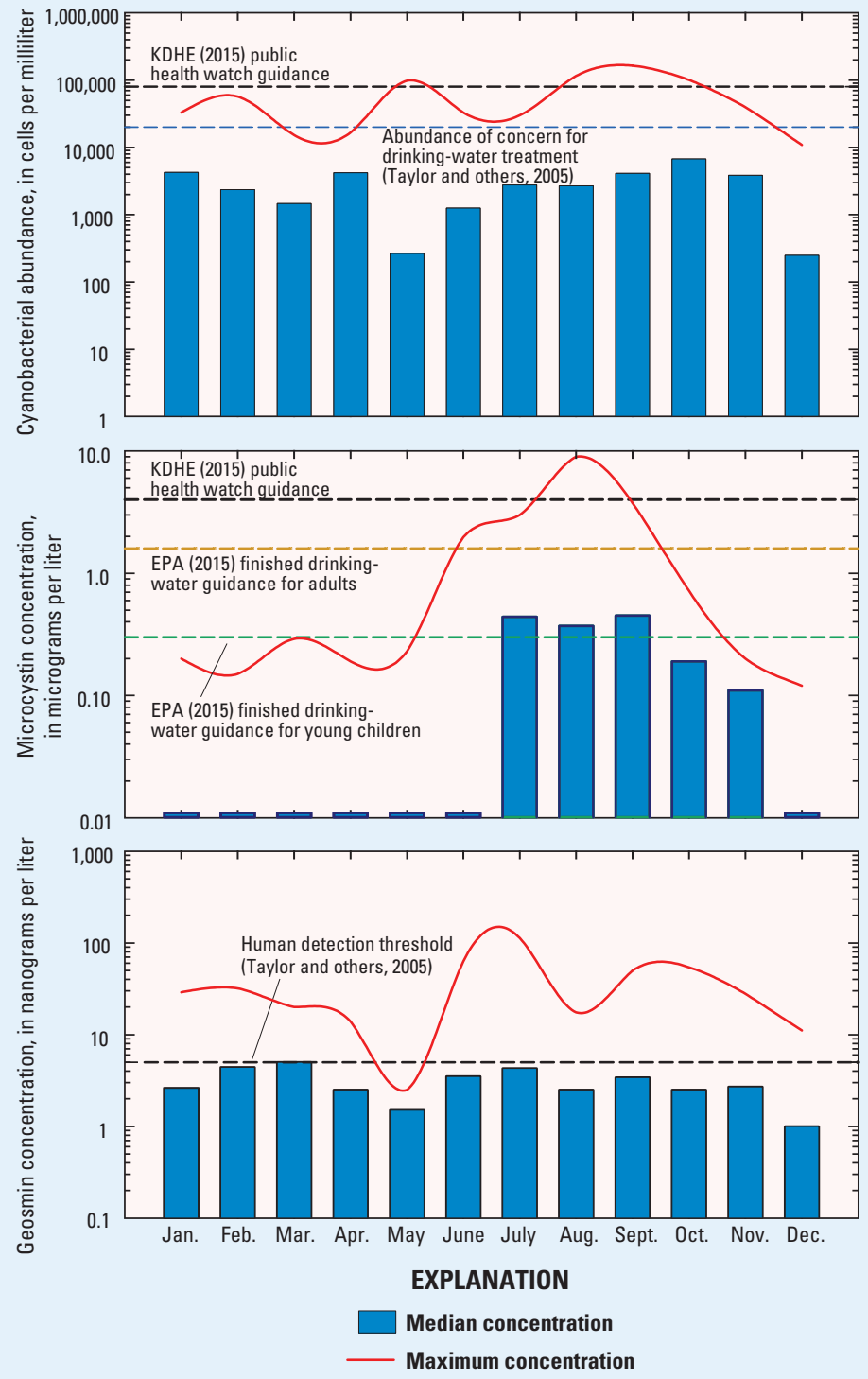

Figure 4. Cyanobacteria, microcystin, and geosmin in Cheney Reservoir, 2001-2016. [KDHE, Kansas Department of Health and Environment; EPA, U.S. Environmental Protection Agency]

concentrations, which stimulate algal growth, and a negative association with sediment concentrations, which decrease the amount of available light for photosynthesis. Cyanobacterial (and other algal) growth in Cheney Reservoir is likely limited by light rather than nutrients (Christensen and others, 2006); therefore, decreasing sediment loads to the reservoir without also decreasing nutrient loads may result in increased cyanobacterial blooms. Despite the general association with light and nutrients,
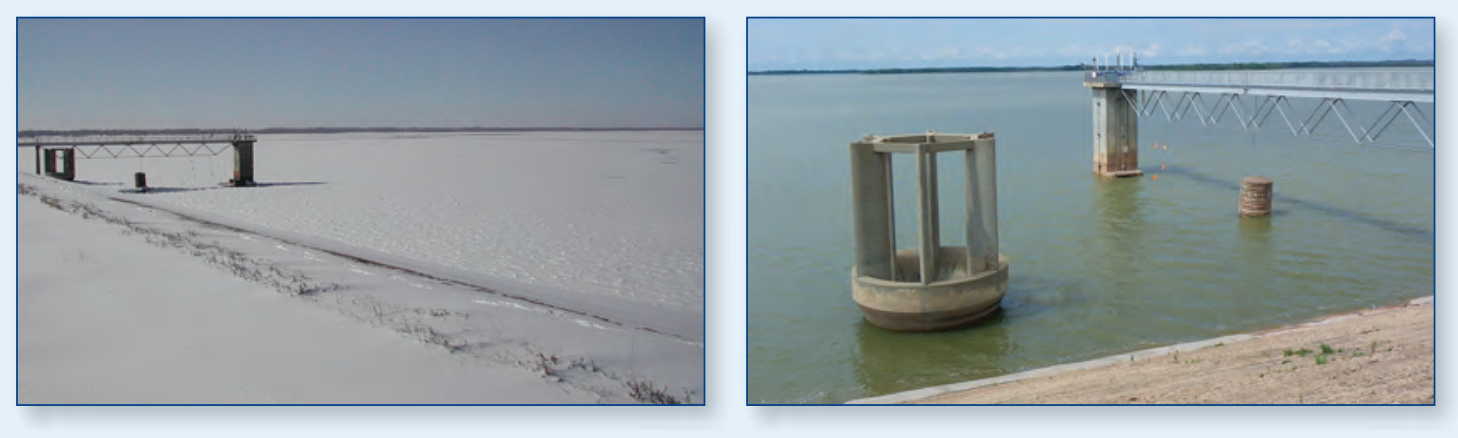

Cheney Reservoir, south-central Kansas in January (left) and August (right). Photographs by U.S. Geological Survey. 
the presence of cyanobacteria, microcystin, and geosmin are affected by the complex interaction of biological, physicochemical, and hydrological factors (Christensen and others, 2006; Harris and others, 2016).

Water quality in Cheney Reservoir has been measured hourly since 2001 to serve as a notification system for changing waterquality conditions that may affect drinking-water treatment. Water-quality models were developed to estimate the probability of microcystin and geosmin in Cheney Reservoir and hourly probabilities are available through the USGS National Real-Time Water Quality website at https://nrtwq.usgs.gov/. The original model for microcystin (Stone and others, 2013) has been robust; however, the geosmin model has changed over time, likely because of changing environmental conditions that affect occurrence (Graham and others, 2017). The need to update and refine the geosmin model demonstrates the need for continuous re-evaluation of models to maximize performance and minimize uncertainty.

\section{Ongoing Activities}

The USGS water-quality studies in the Cheney Reservoir watershed during the past two decades (1996-2016) have identified sources of water-quality constituents like nutrients and sediment and quantified their concentrations and loads. In addition, the occurrence and some of the causal factors of cyanobacteria, cyanotoxins, and taste-and-odor compounds in Cheney Reservoir are now better understood. Knowledge gained from USGS studies in the Cheney Reservoir watershed has assisted in the development, implementation, maintenance, and assessment of watershed-management goals and plans.

To achieve watershed-management goals, approximately 1,500 contracts were implemented in the Cheney Reservoir watershed between 1994 and 2011 and Conservation Reserve Program (CRP) land increased by approximately 20,475 acres (Stone and others, 2013). Implementation of BMPs and other watershed changes to improve water-quality conditions is a longterm management strategy and 20 years of data collection allows documentation of changes in inflow and reservoir conditions as a result of this management strategy. The USGS studies in the Cheney Reservoir watershed are currently (2017) scheduled to continue through 2018. Ongoing efforts are focused on continued data collection (long-term water-quality monitoring study sites at the inflow and outflow of the reservoir; fig. 1), evaluating changes in water quality over time with respect to BMP implementation, and linking inflow and reservoir processes to identify the unique characteristics of cyanobacterial-event years. Understanding the effects on, and changes in, water-quality conditions over time will provide necessary information to help inform management decisions to ensure the longevity of Cheney Reservoir as a drinking-water supply and recreational resource.

\section{For additional information concerning this publication, contact: Director, USGS Kansas Water Science Center 4821 Quail Crest Place Lawrence, KS 66049 (785) 842-9909}

Or visit the Kansas Water Science Center website at: https://ks.water.usgs.gov

\section{References Cited}

Cheney Reservoir Task Force, 1994, Watershed pollution management plan for North Fork Ninnescah Watershed and Cheney Reservoir: Final Report, $22 \mathrm{p}$.

Christensen, V.G., Graham, J.L., Milligan, C.R., Pope, L.M., and Ziegler, A.C., 2006, Water quality and relation to taste-and-odor compounds in the North Fork Ninnescah River and Cheney Reservoir, South-Central Kansas, 1997-2003: U.S. Geological Survey WaterResources Investigations Report 2006-5095, 43 p.

Graham, J.L., Foster, G.M., Williams, T.J., Kramer, A.R., and Harris, T.D., 2017, Occurrence of cyanobacteria, microcystin, and taste-andodor compounds in Cheney Reservoir, Kansas, 2001-16: U.S. Geological Survey Scientific Investigations Report 2017-5016, 57 p., https://doi.org/10.3133/sir20175016.

Harris, T.D., Smith, V.H., Graham, J.L., Van de Waal, D.B., Tedesco, L.P., and Clercin, N., 2016, Combined effects of nitrogen to phosphorus and nitrate to ammonia ratios on cyanobacterial metabolite concentrations in eutrophic Midwestern USA reservoirs: Inland Waters, v. 6 , no. 2, p. 199-210.

Kansas Department of Health and Environment, 2015, Policy-Guidelines for addressing harmful algal blooms in Kansas recreational waters: Kansas Department of Health and Environment Internal Directive 1101.1, accessed September 2016 at http://www.kdheks. gov/algae-illness/download/HAB_policy.pdf.

Mau, D.P., 2001, Sediment deposition and trends and transport of phosphorus and other chemical constituents, Cheney Reservoir Basin, South-central Kansas: U.S. Geological Survey Water-Resources Investigations Report 01-4085, 40 p.

Otten, T.G., Graham, J.L., Harris, T.D., and Dreher, T.W., 2016, Elucidation of taste- and odor-producing bacteria and toxigenic cyanobacteria in a Midwestern drinking water supply reservoir by shotgun metagenomics analysis: Applied and Environmental Microbiology, v. 82 , no. 17 , p. $5410-5420$.

Pope, L.M., Milligan, C.R., and Mau, D.P., 2002, Historical contributions of phosphorus from natural and agricultural sources and implications for stream water quality, Cheney Reservoir basin, southcentral Kansas: U.S. Geological Survey Water-Resources Investigation Report 02-4021, 25 p.

Stone, M.L., Graham, J.L., and Gatotho, J.W., 2013, Continuous realtime water-quality monitoring and regression analysis to compute constituent concentrations and loads in the North Fork Ninnescah River upstream from Cheney Reservoir, south-central Kansas, 1999-2012: U.S. Geological Survey Scientific Investigations Report 2013-5071, 44 p.

Stone, M.L., Juracek, K.E., Graham, J.L., and Foster, G.M., 2015, Quantifying suspended sediment loads delivered to Cheney Reservoir, Kansas - Temporal patterns and management implications: Journal of Soil and Water Conservation, v. 70, no. 2, p. 91-100.

Taylor, W.D., Losee, R.F., Torobin, Marcia, Izaguirre, George, Sass, Debra, Khiari, Djanette, and Atasi, Khalil, 2005, Early warning and management of surface water taste-and-odor events: American Water Works Association Water Research Foundation, 268 p.

U.S. Environmental Protection Agency, 2015, Recommendations for public water systems to manage cyanotoxins in drinking water: U.S. Environmental Protection Agency, EPA 815-R-15-010, accessed September 2016 at https:/www.epa.gov/sites/production/ files/2015-06/documents/cyanotoxin-management-drinking-water. pdf.

Publishing support provided by: Rolla Publishing Service Center
ISSN 2327-6916 (print) ISSN 2327-6932 (online) https://doi.org/10.3133/fs20173019 